\title{
Sardine Oil Purification with Winterization
}

\section{SUGENG HERI SUSENO*, ERWANITA DYAH PURI SINTOKO, AGOES M. JACOEB and NADIA FITRIANA}

Departement of Aquatic Products Technology, Faculty of Fisheries and Marine Science, Bogor Agricultural University, Jalan Agatis Kampus IPB Dramaga Bogor 16680, Indonesia.

${ }^{\star}$ Corresponding author E-mail: sug_thp@yahoo.com

http://dx.doi.org/10.13005/ojc/330658

(Received: May 03, 2017; Accepted: June 01, 2017)

\begin{abstract}
Sardine oil was dominated by palmitic acid which amount of $20.25 \%$. It can be reduced by purification in 4 stages: degumming, neutralization, bleaching, and winterization. This study aimed to reduce the saturated fatty acid in refined fish oil using winterization with various temperature treatment. The best quality of refined oil was obtained by centrifugation treatment at 10,000 rpm, Magnesol XL $1 \%$, and winterization at temperature of $4^{\circ} \mathrm{C}$. The treatment resulted free fatty acids of $0.75 \%$, peroxide value of $5.16 \mathrm{meq} / \mathrm{kg}$, acid value of $1.63 \mathrm{mg} \mathrm{KOH} / \mathrm{g}$, p-anisidin value of 12.87 $\mathrm{meq} / \mathrm{kg}$, total oxidation value of $23.19 \mathrm{meq} / \mathrm{kg}$, and clarity value of $39.15 \% \mathrm{~T}$. Before winterization, the saturated fatty acids of refined oil was accounted for $35.22 \%(w / w)$, then reduced to $31.06 \%(w /$ w) after winterization.
\end{abstract}

Keywords: Purification, Sardine oil, Saturated fatty acids, Winterization.

\section{INTRODUCTION}

Development of pharmaceutical and aquaculture industry, as well as public awareness of food consumption enriched by omega-3 have great influence for increase of fish oil demand. That increase demand might provide a couple of opportunities and challenges for manufacturers of fish oil to produce the best quality of fish oil. Sardines oil (Sardinella sp.) was one of the dominant fishery resources in Bali strait, Indonesia which had production volume reaching of 5,573 tons in $2012^{1}$. A plentiful amount of production was generally used by canning and fishmeal industry producing fish oil as by-product.
Fish oil as by-product from fishmeal industry was crude fish oil that had not been utilized optimally since they had low quality with unattractive colors, high free fatty acid and peroxide ${ }^{2}$. The fish oil was necessary to be purified before further utilization. Fish oil purification aimed to obtain refined fish oil that was free from undesirable components or impurities that was carried out with 3 stages: degumming, neutralization, and bleaching ${ }^{3}$. Suseno et al. $^{4}$ in the purification of fish oil by centrifugation and bleaching methods produced refined fish oil with free fatty acid and peroxide value above the maximum limit of International Fish Oil Standards (IFOS). It showed that the level of free fatty acids and peroxide value were necessary to be reduced by degumming stage. 
By-product of fish oil from fishmeal industry contained high level of saturated fatty acid. Suseno ${ }^{5}$ stated that sardine oil was dominated by saturated fatty acids which was palmitic acid C16:0 (20.25\%). Consumption of saturated fatty acids might increase the level of LDL cholesterol (bad cholesterol) and HDL (good cholesterol), therefore it will automatically rise the total cholesterol ${ }^{6}$. In addition, the high level of saturated fatty acids could be reduced by winterization. Moghanjoghi et al., ${ }^{7}$ stated that the refining process would just lower the free fatty acid and peroxide value, whereas there was no effect for fatty acid profile, so that winterization was necessary. Moghanjoghi et al., ${ }^{7}$ revealed a decrease in the value of saturated fatty acids in fish oil of Clupeonella delicatula from $33.16 \%$ to $21.34 \%$ after winterization. Winterization was defined as the purification which not only increase oil unsaturation, but also it was able to eliminate most of the impurities components ${ }^{3}$. Purification of fish oil was expected to increase the added value of the fish oil by-product from fishmeal industry. This study aimed to reduce the saturated fatty acid using winterization in various temperature treatment in fish oil that had been purified before by centrifugation in degumming salt and bleaching adsorbent.

\section{METHODOLOGY}

The main material used in this study were crude fish oil by-product of sardine (Sardinella sp.) fishmeal industry in PT. Hosana Buana Tunggal, Bali, Indonesia and Magnesol XL as adsorbent. Chemical used for fish oil quality analysis were Ethanol96\%, phenolphthalein indicator, Potassium hydroxide $0.1 \mathrm{~N}$, Chloroform, Acetic acid, saturated Potassium iodide (KI) solution, distilled water, starch indicator $1 \%$, Sodium thiosulfate $0.1 \mathrm{~N}$, and $\mathrm{n}$-hexane. While chemicals used for the analysis of fatty acid profiles were Supelco TM37 Component standard fatty acid methyl esters (FAME) Mix, Sodium hydroxide $0.5 \mathrm{~N}$ in methanol, Boron trifluoride $\left(\mathrm{BF}_{3}\right)$, saturated Sodium chloride $(\mathrm{NaCl})$, isooctane, and anhydrous Sodium sulfate.

The tools used were Erlenmeyer (Herma, Germany), digital scales (CHQ, Taiwan, 0.01 grams), electric stove (Maspion, Japan), thermometers (Pyrex, Germany), pipette Mohr (Pyrex, Germany), burette (Pyrex, Germany), water bath (Julabo U3), hot plate stirrer (Corning, Germany, Model PC-4200, 60-1150 rpm, 230 V), magnetic stirring bar, centrifugation (PLC series), centrifugation (Beckman Model J2-21), UV-Vis spectrophotometer (UV-Vis spektronik IR-U-2500, LaboMed), gas chromatography device (Shimadzu GC Model 2010 Plus).

\section{Procedure}

The initial study was characterized the peroxide value and free fatty acid content of crude fish oil. Research procedure was divided into two, namely purification of crude oil to obtain refined oil with the best characteristics, and followed by winterization to obtain fish oil with low level of saturated fatty acids. Purification of crude oil was done by three stages: degumming, neutralization, and bleaching. Degumming was carried out twice using water and salt. First degumming used 5\% water of total oil used $(\mathrm{v} / \mathrm{v})$,the mixture was stirred at $50^{\circ} \mathrm{C}$ for $15 \mathrm{~min}$. at $800 \mathrm{rpm}$. Second degumming using oil and salt solution $3 \%(\mathrm{w} / \mathrm{v})$ in ratio of $1: 3$ $(\mathrm{v} / \mathrm{v})$. The mixture was stirred at $50^{\circ} \mathrm{C}$ for $20 \mathrm{~min}$. at $800 \mathrm{rpm}$. Centrifugation treatment was given in salt degumming, using speed 3000,6000 , and 10,000 rpm for $10 \mathrm{~min}$. at room temperature. Neutralization was carried out by $\mathrm{NaOH} 20^{\circ}$ Bewhich stirred at $50^{\circ} \mathrm{C}$ for $15 \mathrm{~min}$. at $800 \mathrm{rpm}$, followed by bleaching with Magnesol XL treatment as many as 1, 3, and $5 \%$ $(\mathrm{w} / \mathrm{w})$ which stirred at room temperature for 20 minutes at $800 \mathrm{rpm}$. In addition, centrifugation at $10,000 \mathrm{rpm}$ for $10 \mathrm{~min}$. was carried out after both neutralization and bleaching were done.

The purification were divided into 5 treatments of centrifugation speed and Magnesol $\mathrm{XL}$ concentration, there were $\mathrm{A}$ : centrifugation at $10,000 \mathrm{rpm}$, magnesol 1\%; B: centrifugation at $10,000 \mathrm{rpm}$, magnesol 3\%; C: centrifugation at 10,000 rpm, magnesol 5\%; D: centrifugation 6,000 rpm, magnesol 5\%; E: centrifugation 3,000 rpm, magnesol $5 \%$. The quality of refined oil was then analyzed based on its level of free fatty acid content ${ }^{8}$, peroxide value $^{9}, \mathrm{p}$-anisidine value ${ }^{10}$, total oxidation value $^{11}$, and the clarity ${ }^{12}$. Refined fish oil obtained from the best treatment (based on the results of the test parameters) in the first step followed by winterization step with temperature treatment. Winterization was carried out by centrifugation at speed of $10,000 \mathrm{rpm}$ using temperature of $4^{\circ} \mathrm{C}, 7^{\circ} \mathrm{C}$, and $10^{\circ} \mathrm{C}$ for 15 minutes. The fish oil analyzed further by percent yield, free fatty acid content and acid 
value $^{8}$, peroxide value ${ }^{9}, p$-anisidine value ${ }^{10}$, total oxidation value ${ }^{11}$, the clarity level ${ }^{12}$, and the fatty acid profile ${ }^{9}$.

\section{Statistical analysis}

The experimental design was Completely Randomized Design (CRD). Obtained data were processed with Microsoft Excel 2010, then the analysis of variance (ANOVA) was calculated by Minitab 17 to see the differences between treatments. The statistical test performed on the parameters of free fatty acid content, acid value, peroxide value, $p$-anisidine value, total oxidation value, and clarity level. This study was conducted twice replicates by the design model according to Steel and Torrie ${ }^{13}$
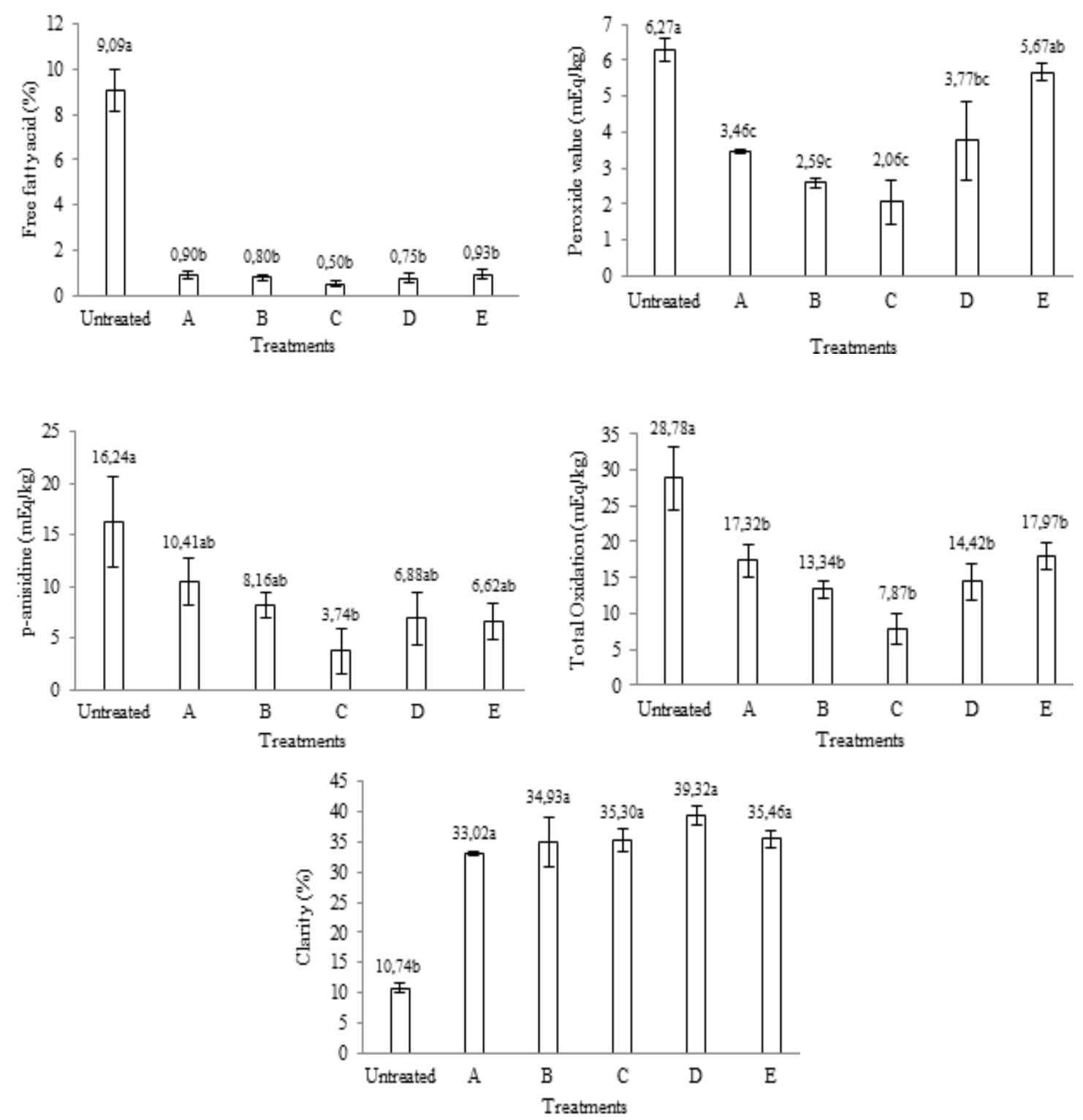

Fig. 1. Parameters of refined fish oil quality (A: centrifugation at 10,000 rpm, magnesol 1\%; B: centrifugation at 10,000 rpm, magnesol $3 \%$; C: centrifugation at 10,000 rpm, magnesol $5 \%$; $D$ : centrifugation 6,000 rpm, magnesol 5\%; E: centrifugation 3,000 rpm, magnesol 5\%) 


\section{RESULTS AND DISCUSSION}

Crude fish oil had blackish brown color with a fishy odor. It had a free fatty acid content of $8.16 \pm 1.18 \%$ and peroxide value of $4.95 \pm 1.16 \mathrm{meq} /$ $\mathrm{kg}$. According IFOS ${ }^{14}$, the standard value of free fatty acids and peroxide value should be less than or equal to $1.50 \%$ and $5 \mathrm{meq} / \mathrm{kg}$, respectively. The crude oil had a free fatty acid content which was not in accordance with the standards while the peroxide values had met the standards. Estiasih et al., ${ }^{15}$ stated that the value of free fatty acids and peroxide in fish oil byproduct from fishmeal industry were $5.88 \%$ and $3.29 \mathrm{meq} / \mathrm{kg}$, respectively.

\section{Purification of crude fish oil}

Crude fish oil was purified by degumming (water and salt), neutralization and bleaching steps. Degumming was carried out twice as the first degumming produced slightly residue, so that the gum was not separated maximally. Refined fish oil quality were analyzed for some parameters, there were free fatty acid content, peroxide value, $\mathrm{p}$-anisidine value, total oxidation value and clarity which can be seen in Figure. 1.

Free fatty acid showed no significant difference among treatments, but there were significant differences to untreated. Therefore the best treatment based on the free fatty acid content was treatment $A$ (centrifuged at $10,000 \mathrm{rpm}$, Magnesol XL1\%) which amount of $0.90 \pm 0.18 \%$. The content of free fatty acids met the standards of IFOS ${ }^{14}$ for free fatty acid $(\leq 1.50 \%)$. Suseno et al., ${ }^{4}$ who conducted on sardine fish oil, demonstrated that the combination of centrifugation $8500 \mathrm{rpm}$ and 5\% bentonite adsorbent were capable of lowering free fatty acid content up to $27.35 \pm 0.00 \%$. Another study conducted by Rozi ${ }^{16}$ in the bleaching of shark liver oil showed that the difference concentration of Magnesol XL 1, 3, and 5\% produced no significant free fatty acids content as many as $0.28 \pm 0.00 \%$. Differences decrease in the level of free fatty acids content might occur by the different stages of purification used. In the degumming stage, free fatty acids which had polar group of carbonyl $(C=O)$ and hydroxyl group $(\mathrm{C}-\mathrm{OH})$ would be carried by vapor in the heating process ${ }^{17}$. Moreover, the different types of adsorbents could also affect the decrease of free fatty acid content. The type of adsorbent would have differences in polarity, active surface, surface area, porosity, particle size, $\mathrm{pH}$ and water content ${ }^{18}$.

The result of peroxide value showed significant difference between the treatment $E$ with other treatments, however treatment $D$ showed no significant difference with treatment $A, B$, and $C$. The best treatment based on peroxide value was in the treatment $A$ (centrifuged at $10,000 \mathrm{rpm}$, Magnesol XL1\%) which amount of $3.46 \pm 0.06$ meq/ $\mathrm{kg}$. According IFOS ${ }^{14}$, peroxide value which obtained from treatment $A, B, C$, and $D$ had met the standards $(5 \mathrm{meq} / \mathrm{kg}$ ). The decrease of peroxide value was affected more by the treatment of centrifugation at degumming of salt. Budiadnyani et al. ${ }^{19}$ stated that degumming was able to reduce oxidation products expressed by peroxide value. High concentration of adsorbent allowed the absorption of impurities component occurred maximally, however it also allowed the natural antioxidants contained in pigments absorbed thus affecting the stability of oxidation of fish oil ${ }^{4}$.

Table. 1: The value of winterized fish oil quality with various winterization temperature treatment

\begin{tabular}{|c|c|c|c|c|c|}
\hline \multirow[t]{2}{*}{ Parameters } & \multirow[b]{2}{*}{ Room Temperature } & \multicolumn{3}{|c|}{ Treatments } & \multirow[b]{2}{*}{ Standard } \\
\hline & & $4^{\circ} \mathrm{C}$ & $7^{\circ} \mathrm{C}$ & $10^{\circ} \mathrm{C}$ & \\
\hline Yield (\%) & $100.00 \pm 0.00^{a}$ & $36.00 \pm 1.41^{d}$ & $56.00 \pm 4.51^{c}$ & $82.00 \pm 3.72^{b}$ & - \\
\hline FFA (\%) & $0.77 \pm 0.09^{a}$ & $0.75 \pm 0.06^{a}$ & $0.63 \pm 0.01^{a}$ & $0.66 \pm 0.03^{a}$ & 1.50 \\
\hline $\mathrm{AV}(\mathrm{mg} \mathrm{KOH} / \mathrm{kg})$ & $1.68 \pm 0.21^{a}$ & $1.63 \pm 0.12^{\mathrm{a}}$ & $1.38 \pm 0.03^{a}$ & $1.45 \pm 0.06^{a}$ & $<3.00$ \\
\hline PV (meq/kg) & $10.00 \pm 0.34^{a}$ & $5.16 \pm 0.09^{b}$ & $7.12 \pm 0.53^{\mathrm{ab}}$ & $6.37 \pm 1.60^{\mathrm{b}}$ & $<5.00$ \\
\hline $\mathrm{p}$-anisidine $(\mathrm{meq} / \mathrm{kg})$ & $20.11 \pm 1.24^{a}$ & $12.87 \pm 0.39^{b}$ & $14.77 \pm 0.67^{b}$ & $19.89 \pm 0.15^{a}$ & $<20.00$ \\
\hline Totox (meq/kg) & $40.11 \pm 0.53^{a}$ & $23.19 \pm 0.59^{c}$ & $29.01 \pm 0.39^{b c}$ & $32.62 \pm 3.04^{b}$ & $<26.00$ \\
\hline Clarity (\%T) & $34.13 \pm 1.20^{b}$ & $39.15 \pm 0.98^{a}$ & $37.12 \pm 1.04^{a b}$ & $35.21 \pm 0.88^{a b}$ & - \\
\hline
\end{tabular}

${ }^{*}$ IFOS [14] 
P-anisidine values showed no significant difference among the treatments, however there was significant difference between the treatment $C$ to untreated. The best treatment based on a $p$-anisidine value was treatment $C$ (centrifuged at $10,000 \mathrm{rpm}$, Magnesol XL 5\%) as many as $3.74 \pm 2.15 \mathrm{meq} / \mathrm{kg}$. Overall $p$-anisidine values were met the IFOS standards ${ }^{14}$ which is less than or equal to $20 \mathrm{meq} / \mathrm{kg}$. Suseno et al., ${ }^{20}$ stated that the addition of Magnesol XL 5\% in the bleaching of sardines oil produced $p$-anisidin reduction up to $62.66 \%$. Suseno et al.. ${ }^{21}$ in the purification of fish oil treated twice by centrifugation (10,500 rpm and 10,000 rpm) before bleaching showed that bleaching which had initial centrifugation could reduce the $\mathrm{p}$-anisidine value significantly.

Total oxidation value (totox) was determination of all oil oxidation products. The totox showed no significant difference among the treatments, however there were significant differences to untreated. The best treatment based on totox values was treatment $A$ (centrifuged at $10,000 \mathrm{rpm}$, Magnesol XL1\%) which amount of $17.32 \pm 2.28 \mathrm{meq} / \mathrm{kg}$. The totox value met the standards IFOS ${ }^{14}$ which was less than or equal to $26 \mathrm{meq} / \mathrm{kg}$. Rozi ${ }^{16}$ mentioned that shark liver oil which was bleached by Magnesol XL 1, 3, and 5\% showed no significant value of totox. Meanwhile, Suseno et al., ${ }^{21}$ stated that the addition of adsorbent in sardine oil refining which had primary centrifugation was able to reduce the totox significantly.

The physical quality of refined fish oil were analyzed by clarity. The clarity values showed no significant difference among the treatments, yet there were significant differences to untreated. The best treatment based on the clarity wastreatment $\mathrm{A}$ (centrifuged at 10,000 rpm, Magnesol XL1\%). Rozi ${ }^{16}$ stated that bleaching using Magnesol XI had no significant difference on clarity at a wavelength of $450 \mathrm{~nm}$. Suseno et al. ${ }^{22}$ stated that purification of fish oil using Magnesol XL which centrifuged at

Table. 2: Comparison of fatty acid profiles of fish oil A with winterized fish oil in various temperature treatment

\begin{tabular}{lccccc}
\hline Fatty Acids & \multicolumn{5}{c}{ Results (\%w/w) } \\
& Fish & $\begin{array}{c}\text { Room } \\
\text { Temperature }\end{array}$ & $4^{\circ} \mathrm{C}$ & $7^{\circ} \mathrm{C}$ & $10^{\circ} \mathrm{C}$ \\
& Oil A & & & \\
\hline Lauric acid, C12:0 & 0.08 & 0.07 & 0.07 & 0.07 & 0.07 \\
Tridecanoic acid, C13:0 & 0.04 & 0.04 & 0.04 & 0.04 & 0.04 \\
Myristic acid, C14:0 & 10.43 & 9.76 & 9.38 & 10.21 & 9.89 \\
Pentadecanoic acid, C15:0 & 0.53 & 0.48 & 0.46 & 0.49 & 0.49 \\
Palmitic acid, C16:0 & 19.08 & 18.01 & 16.74 & 18.29 & 17.75 \\
Heptadecanoic acid, C17:0 & 0.63 & 0.61 & 0.55 & 0.59 & 0.57 \\
Stearic acid, C18:0 & 3.77 & 3.60 & 3.24 & 3.49 & 3.43 \\
Arachidic acid, C20:0 & 0.35 & 0.32 & 0.29 & 0.30 & 0.30 \\
Heneicosanoic acid, C21:0 & 0.06 & 0.06 & 0.05 & 0.05 & 0.05 \\
Behenic acid, C22:0 & 0.21 & 0.20 & 0.19 & 0.19 & 0.25 \\
Tricosanoic acid, C23:0 & 0.04 & 0.03 & 0.05 & 0.04 & 0.03 \\
@ SFA & 35.22 & 33.18 & 31.06 & 33.76 & 32.87 \\
Miristoleic acid, C14:1 & 0.02 & 0.02 & 0.02 & 0.02 & 0.02 \\
Palmitoleic acid, C16:1 & 8.12 & 7.75 & 7.70 & 8.41 & 8.27 \\
Cis-10-Heptadecanoic acid, C17:1 & 0.65 & 0.63 & 0.60 & 0.63 & 0.67 \\
Elaidic acid, C18:1ù9t & 0.08 & 0.08 & 0.07 & 0.08 & 0.08 \\
Oleic acid, C18:1ù9c & 5.45 & 5.23 & 5.13 & 5.63 & 5.54 \\
Cis-11-Eicosanoic acid, C20:1 & 1.67 & 1.62 & 1.52 & 1.69 & 1.63 \\
Nervonic acid, C24:1 & 0.64 & 0.60 & 0.56 & 0.61 & 0.58 \\
○ MUFA & 16.63 & 15.93 & 15.60 & 17.07 & 16.79 \\
\hline
\end{tabular}


$10,000 \mathrm{rpm}$ for $30 \mathrm{~min}$. was able to improve the clarity value. Tambunan et al. ${ }^{23}$ stated that centrifugation could improve the clarity of fish oil, where the clarity value increased at a speed of 10,500 rpm of centrifugation for 30 minutes.

The results of the five parameters of refined fish oil purified by centrifugation and bleaching treatment described showed that the best fish oil was obtained in the treatment $A$ (centrifuged at 10,000 rpm, Magnesol XL1\%). Analysis of fatty acid profile of refined fish oil was conducted to determine the levels of saturated fatty acids in fish oil before winterization. Total saturated fatty acids in fish oil A was $35.22 \%$, with the predominant saturated fatty acids were $10.43 \%$ myristic acid, $19.08 \%$ palmitic acid, and $3.77 \%$ stearic acid. Fatty acid profile of the best refined oil (treatment $A$ ) was presented in Table 2.

Table. 3: Fatty acid profile of residues with various winterization temperature treatment

\begin{tabular}{|c|c|c|c|}
\hline \multirow[t]{2}{*}{ Fatty Acids } & \multicolumn{3}{|c|}{ Results (\%w/w) } \\
\hline & $4^{\circ} \mathrm{C}$ & $7^{\circ} \mathrm{C}$ & $10^{\circ} \mathrm{C}$ \\
\hline Lauric acid, C12:0 & 0.08 & 0.07 & 0.07 \\
\hline Tridecanoic acid, C13:0 & 0.04 & 0.04 & 0.04 \\
\hline Myristic acid, C14:0 & 10.96 & 10.28 & 9.38 \\
\hline Pentadecanoic acid, C15:0 & 0.56 & 0.52 & 0.47 \\
\hline Palmitic acid, C16:0 & 20.65 & 19.44 & 17.65 \\
\hline Heptadecanoic acid, C17:0 & 0.68 & 0.64 & 0.58 \\
\hline Stearic acid, C18:0 & 4.12 & 3.88 & 3.47 \\
\hline Arachidonic acid, C20:0 & 0.37 & 0.35 & 0.32 \\
\hline Heneicosanoic acid, C21:0 & 0.07 & 0.06 & 0.06 \\
\hline Behenic acid, C22:0 & 0.22 & 0.21 & 0.19 \\
\hline Tricosanoic acid, C23:0 & 0.05 & 0.04 & 0.04 \\
\hline (C) SFA & 37.80 & 35.53 & 32.27 \\
\hline Miristoleic acid, C14:1 & 0.02 & 0.02 & 0.02 \\
\hline Palmitoleic acid, C16:1 & 7.95 & 7.54 & 6.97 \\
\hline Cis-10-Heptadecanoic acid, C17:1 & 0.64 & 0.60 & 0.54 \\
\hline Elaidic acid, C18:1ù9t & 0.07 & 0.07 & 0.06 \\
\hline Oleic acid, C18:1ù9c & 5.33 & 5.08 & 4.72 \\
\hline Cis-11-Eicosanoic acid, C20:1 & 1.63 & 1.56 & 1.46 \\
\hline Nervonic acid, C24:1 & 0.66 & 0.62 & 0.58 \\
\hline (C) MUFA & 16.30 & 15.49 & 14.35 \\
\hline Linolelaidic acid, C18:2ù9t & 0.05 & 0.05 & 0.05 \\
\hline Linoleic acid, C18:2ù6c & 1.27 & 1.21 & 1.13 \\
\hline c-Linolenic acid, C18:3ù 6 & 0.26 & 0.25 & 0.22 \\
\hline Linolenic acid, C18:3ù3 & 0.50 & 0.48 & 0.44 \\
\hline Cis-11,14-Eicosedienoic acid, C20:2 & 0.16 & 0.15 & 0.14 \\
\hline Cis-8,11,14-Eicosetrienoic acid, C20:3ù6 & 0.29 & 0.27 & 0.25 \\
\hline Arachidonic acid, C20:4ù6 & 2.79 & 2.66 & 2.48 \\
\hline Cis-13,16-Docosadienoic acid, C22:2 & 0.05 & 0.05 & 0.04 \\
\hline Cis-5,8,11,14,17-Eicosapentaenoic acid, C20:5ù3 & 15.45 & 14.76 & 13.69 \\
\hline Cis-4,7,10,13,16,19-Docosaheksaenoic acid, C22:6ù3 & 17.73 & 16.94 & 15.78 \\
\hline (C) PUFA & 38.55 & 36.82 & 34.22 \\
\hline (C) ù6 & 4.61 & 4.39 & 4.08 \\
\hline (C) ù3 & 33.68 & 32.18 & 29.91 \\
\hline ù6/ù3 & 0.14 & 0.14 & 0.14 \\
\hline Identified & 92.65 & 87.84 & 80.84 \\
\hline
\end{tabular}




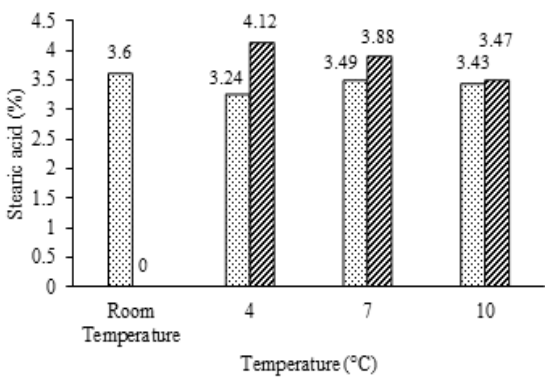

Stearic Fil trate चStearic Residue

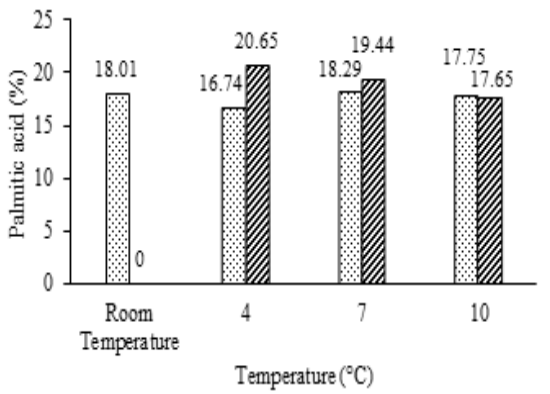

QPalmitic Filtrate aPalmitic Residue

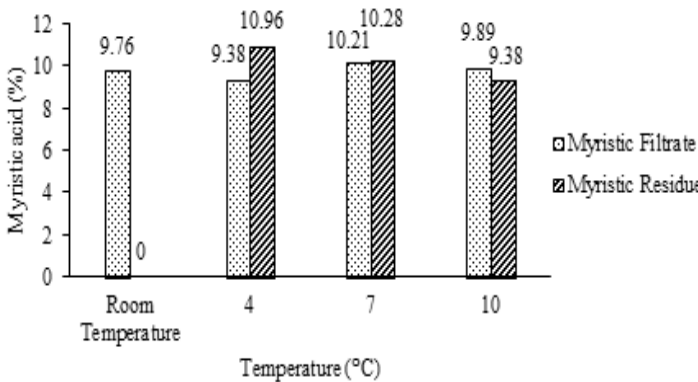

Fig. 2: The value of myristic acid, palmitic acid, and stearic acid in the winterized fish oil with temperature treatment

\section{Winterization}

Winterization was a method to separate oil with glycerol in certain time and temperature. Winterization aimed to eliminate saturated fatty acids or increasing oil unsaturation. Winterization also aimed to increase the concentration of polyunsaturated fatty acids (PUFA) ${ }^{7}$. Refined fish oil obtained was repurified by winterization. The method was divided into three winterization temperature treatment and then compared with refined fish oil at room temperature as an untreatment. Winterized fish oil obtained were analyzed with different quality parameters. The quality of winterized fish oil with various temperature treatment can be seen in Table. 1.

Winterization was carried out using centrifugation at various temperatures to separate the oil pellet which suspected as saturated fatty acids. The yield percentage showed significant difference among all treatments. Yield percentage of fish oil at room temperature treatment was $100 \%$ indicated that oil was not separated with the pellet, which showed that saturated fatty acids in the oil were not separated. The yield decreased with the decrease of temperature. The decrease in temperature caused the crystallization process was more efficient because the temperature reduction increased $^{24}$. Hartel ${ }^{25}$ stated that the rapidness of temperature decrease affected the formation of crystal core, the lower the temperature, the speed of temperature reduction increased. As a result, the crystal core was formed more. The core facilitated a lot of mass in the liquid phase to migrate rapidly to the crystal core. Therefore, most of the mass in the liquid phase that had the ability to crystallize was crystallizing. Moreover, the mass of the liquid phase decreased so that the yield decreased.

Free fatty acid content showed no significant difference between treatments. The highest free fatty acid content was in the treatment of $4^{\circ} \mathrm{C}$ while the lowest was in treatment of $7^{\circ} \mathrm{C}$. Moghanjoghi et al., ${ }^{7}$ examined winterization in kilka fish oil (Clupeonella delicatula) and free fatty acid obtained was $0.1 \%$. Free fatty acid content tend to decline influenced by the increase of temperature. The higher the temperature, the more the decrease of free fatty acids content. This is because the higher the temperature, the water content was reduced so that hydrolysis decreased, as a result free fatty acids decreased as well ${ }^{17}$.

Acid value is a measure of the amount of free fatty acids and calculated based on the molecular weight of the fatty acid or fatty acid mixture. Acid values showed no significant difference among treatments. The highest value was in the treatment of $4^{\circ} \mathrm{C}$ and the lowest was in temperature of $7^{\circ} \mathrm{C}$. The acid number was in line to free fatty acids content ${ }^{26}$. The acid value would be higher as higher as the percentage of free fatty acids in oils ${ }^{27}$.

Peroxide value showed no significant difference among treatments, however there were significant differences to the oil in the room temperature treatment. That was because the crystallization process could be used to separate 
the fatty acids and alkyl derivatives which included peroxide ${ }^{28}$. The highest peroxide value was at $7^{\circ} \mathrm{C}$ while the lowest was at $4^{\circ} \mathrm{C}$. Peroxide values obtained were not in accordance to the IFOS ${ }^{14}$ which was less than or equal to $5 \mathrm{meq} / \mathrm{kg}$.

The next analysis was $p$-anisidine value. The result showed that $p$-anisidine had significant difference value between the treatment at $10^{\circ} \mathrm{C}$ with other treatments, however the treatment at $4^{\circ} \mathrm{C}$ showed no significant value with the treatment at $7^{\circ} \mathrm{C}$. The highest $\mathrm{p}$-anisidine value was in the treatment at $10^{\circ} \mathrm{C}$ while the lowest was at $4^{\circ} \mathrm{C}$. Crexi et al., ${ }^{29}$ stated that after degumming and neutralizing, $p$-anisidine value of winterized oil would be lower than crude oil. P-anisidine value was not always in line with the content of peroxide value $^{30}$, but the high peroxide value might lead to a high number of $\mathrm{p}$-anisidine if the process given allowed further degradation.

Total oxidation value showed significant difference between the treatment at $10^{\circ} \mathrm{C}$ to $4^{\circ} \mathrm{C}$ treatment, however temperature at $7^{\circ} \mathrm{C}$ showed no significant difference with the treatment at $4^{\circ} \mathrm{C}$ and $10^{\circ} \mathrm{C}$. The decrease of total oxidation value of winterized oil showed that the number of peroxides and secondary oxidation products decreased after winterization process.

Clarity showed no significant difference between the treatment at $4^{\circ} \mathrm{C}$ to other treatments, however there were significant differences to the oil at room temperature treatment. The clarity which close to $100 \%$ indicated that fish oil had a good level of clarity. The more primary and secondary oxidation products contained in the oil, the appearance of oil will increasingly turbid and clarity levels would decreased ${ }^{3}$.

Winterized refined oil was analyzed further by gas chromatography to determine the fatty acid profile which showed in Table. 2. The result showed that polyunsaturated fatty acids (PUFA) had higher amount than saturated fatty acids (SFA) and monounsaturated fatty acids (MUFA). Fish oil is the main source of omega-3, so that EPA and DHA are the dominant fatty acid in fish oil. Winterization method could increase the omega- 3 up to $40 \%$ in fish oil ${ }^{31}$. Omega-3 and omega- 6 are essential fatty acids. Both of these essential fatty acids are important for growth and development ${ }^{32}$. The ratio of omega- 6 and omega-3 in winterized fish oil was in the range of 0.14 and 0.13 . This value was in line to the amount of recommended by the UK Department of Health which was less than or equal to $4.0^{33}$. Non essential fatty acids omega-9 in the whole sample treatment was in the range of $5 \%$. Omega-9 fatty acids was essential in lowering bad cholesterol (LDL) and increase the good cholesterol (HDL) in the blood $^{34}$.

Saturated fatty acids decreased after winterization treatment. The lowest saturated fatty acid content was in the treatment of $4^{\circ} \mathrm{C}$. Fish oil before winterization had high levels of saturated fatty acids was amount of $35.22 \%$, then decreased to $31.06 \%$ after winterization at $4^{\circ} \mathrm{C}$. Table. 2 showed that the dominant saturated fatty acids in winterized fish oil were palmitic acid, myristic acid, and stearic acid. Crexi et al. ${ }^{29}$ stated that palmitic acid was the dominant saturated fatty acids in fish. Moghanjoghi et al., ${ }^{7}$ in the research on kilka (Clupeonella delicatula) oil showed a decrease in saturated fatty acids after winterization which was equal to $35.64 \%$ with the dominant saturated fatty acid content were $15.85 \%$ palmitic acid, $2.39 \%$ myristic acid, and $0.44 \%$ stearic acid.

Winterization is a thermo-mechanical process where high melting point and low melting point separated by partial crystallization. Through this winterization, fatty acids with a high melting point solidified and separated from the oil that has a low melting point. Palmitate, myristic, and stearic fatty acid had a high melting point while omega-3 fatty acids had low melting point and would be in the liquid fraction. Therefore, when they were separated, it would result the decrease of saturated fatty acids and omega- 3 fatty acids would increase ${ }^{3}$.

Winterization not only produced fish oil yield, but also produced solids as residue. Analysis of fatty acid profile performed on residue which had been separated from fish oil in the winterization process. Fatty acid profile of residues with temperature treatment can be seen in Table 3. 
Table. 1 Comparison of fatty acid profiles of fish oil A with winterized fish oil in various temperature treatment

The results of showed the highest level of saturated fatty acids was at $4^{\circ} \mathrm{C}$. It showed that most of the saturated fatty acid had been separated into residue. Comparison of filtrate and residue of myristic acid, palmitic acid and stearic acid is showed in Fig. 2. The winterization residue still contained a quite high of omega-3. This could be due to temperature, which was still too high, so that omega-3 had not been entirely separated. Winterization residue was stearin fraction that could be used by industries who required oil with a high degree of saturation such as industrial paints and lubricants ${ }^{3}$.

\section{CONCLUSION}

The lowest level of saturated fatty acids obtained by centrifugation at $10,000 \mathrm{rpm}$ in the degumming salt, $1 \%$ of Magnesol XL adsorbent, and winterization at temperature of $4^{\circ} \mathrm{C}$. Characteristics of refined fish oil obtained were $0.75 \%$ free fatty acid content, $5.16 \mathrm{meq} / \mathrm{kg}$ peroxide value, $1.63 \mathrm{mg} \mathrm{KOH} / \mathrm{kg}$ acid value, $12.87 \mathrm{meq} / \mathrm{kg}$ $\mathrm{p}$-anisidine value, $23.19 \mathrm{meq} / \mathrm{kg}$ total oxidation value, $39.15 \% \mathrm{~T}$ clarity value, $31.06 \%$ saturated fatty acids (dominant saturated fatty acids were $16.74 \%$ palmitic acid, $9.38 \%$ myristic acid, and $3.24 \%$ stearic acid), with saturated fatty acid residues obtained was $37.80 \%$.

\section{REFERENCES}

1. $[\mathrm{KKP}]$ Ministry of Marine Affairs and Fisheries. Volume produksi perikanan tangkap menurut jenis perairan dan provinsi 2012. http://www.statistik.kkp.go.id.2013, (retrieved on 15 November 2016).

2. Ahmadi, K.; Mushollaeni, W. Jurnal Teknologi Pertanian. 2007, 8(2), 71-79.

3. Estiasih, T. Minyak Ikan Teknologi \& Penerapannya untuk Pangan dan Kesehatan. 2009, Yogyakarta (ID): Graha llmu.

4. Suseno, S.H.; Nurjanah.; Jacoeb, A.M.; Sarswati. Advance Journal of Food Science and Technology. 2014, 6(1), 60-67.

5. Suseno, S.H. Production of high quality fish oil: screening for potential sources and value addition through physical treatments [dissertation]. 2011, Malaysia: Universiti Sains Malaysia.

6. Tuminah, S. Media Penelitian dan Pengembangan Kesehatan. 2009, 19, 13-20.

7. Moghanjoghi, M.; Hashemi, G.; Mizani, M.; Gharachorloo, M.; Tavakoli, H.R. Iranian Journal of Fisheries Sciences. 2015, 14(2), 382-392.

8. [AOCS] American Oil Chemists' Society. Free Faty Acids In: Official Methods and Recommended Practices of the American Oil Chemists SocietyChampaign (US): AOCS Press. . $1998, .5(5)$.

9. $[A O A C]$ Association of Official Analytical
Chemist. Official Method of Analysis of The Association of Official Analytical of Chemist. Virginia (US): Published by The Association of Analytical Chemist, inc. 2005.

10. [IUPAC] International Union on Pure an Apllied Chemistry. Standard methods for the analysis of oils arls fats and derivatives, $7^{\text {th }}$ ed. Paquot $C$ dan Hautfenne A, editor., Oxford (GB): Blackwell Scientific. 1987.

11. [AOCS] American Oil Chemists' Society. Official method cd 8-53 peroxide value, cd18-90 p-anisidine value, cg 3-91 recommended practices for assessing oil quality and stability In Official Methods and Recommended Practices of the American Oil Chemists' Society., Urbana (US): AOCS Press. 1997.

12. $[A O A C]$ Association of Official Analytical Chemists. Official methods of analysis, $18^{\text {th }}$ edition., Marylandn (US): Association of Official Analytical Chemists, inc. 1995.

13. Steel, R.G.D.; Torrie, J.H. Principle and Procedures of Statistics: A Biometrical Approach. Sumantri B, Penerjemah., Jakarta (ID): PT Gramedia Pustaka Utama. 1993

14. [IFOS] International Fish Oil Standard.. Fish oil purity standards. 2014http://www. omegavia.com/best-fish-oil-supplement-3/ . 2014, (retrieved 20 November 2016). 
15. Estiasih, T.; Nisa, F.C.; Ahmadi, K.; Umiatun. Jurnal Teknologi dan Industri Pangan. 2005, 15(3), 222-229.

16. Rozi, A. Extraction and purification of silky shark liver oil (Charcarinus falciformis) based international standard [thesis]., Bogor (ID): Sekolah Pascasarjana, Institut Pertanian Bogor. 2016.

17. Fauziah, A.W. Karakterisasi dan penentuan komposisi asam lemak dari pemurnian limbah pengalengan ikan dengan variasi waktu simpan limbah dan suhu pada degumming [undergraduate thesis]., Jember (ID): Jurusan Kimia, Fakultas Matematika dan IImu Pengetahuan Alam, Universitas Jember, 2013.

18. Zhu, Z.Y.; Yates, R.A.; Caldwell, J.D. J. Am. Oil Chem. Soc. 1994, 71, 189-194.

19. Budiadnyani, I.G.A.; Estiasih, T.; Yunianta. Journal of Life Science and Biomedicine. 2015, 5(5), 132-136.

20. Suseno, S.H.; Musbah, M.; Ruspatti, N.P. Prosiding Seminar Nasional Kelautan Universitas Trunojoyo Madura. 2016, 48-56.

21. Suseno, S.H.; Syari, C.; Zakiyah, E.R.; Jacoeb, A.M.; Izaki, A.Y.; Saraswati; Hayati, S. World Journal of Fish and Marine Sciences. 2014, 6(5), 435-440.

22. Suseno, S.H.; Tajul, A.Y.; Wan Nadiah, W.A. International Food Journal. 2011, 18, 255-264.

23. Tambunan, J.E.; Ibrahim, B; Suseno, S.H. Global Journal of Biology, Agriculture, and
Health Science. 2013, 2(4), 196-202.

24. Ahmadi, K.; Estiasih, T. Jurnal Teknologi dan Industri Pangan. 2011, 22(2), 142-149.

25. Hartel, R.W. Crystallization in Foods., Denver (US): A Wolters Kluwer Co. 2001

26. Pramestia, S.P.; Riyanto, B.; Trilaksani, W. 2015. Jurnal Pengolahan Hasil Perikanan Indonesia. 2015, 18(2), 162-176.

27. Feryana, I.W.K.; Suseno, S.H.; Nurjanah. 2014. Jurnal Pengolahan Hasil Perikanan Indonesia. 2014, 16(3), 207-214.

28. Estiasih, T. Jurnal Teknologi Pertanian. 2006, 7(1), 61-70.

29. Crexi, V.T.; Monte, L.M.; Soares, L.A.dS.; Pinto, L.A.A. 2010. Food Chemistry. 2010, 1(19), 945-950.

30. Guillén, M.D.; Cabo, N. Food Chemistry. 2002, 77, 503-510.

31. Okoth, M.W.; Imungi, J.K.; Aloo, J.O. Food Science and Quality Management. 2015, 46, 44-54.

32. Shannon, J.; King, I.B.; Moshofsky, R.; Lampe, J.W.; Gao, D.L.; Ray, R.M.; Thomas, D.B. The American Journal of Clinical Nutrition. 2007, 85, 1090-1097.

33. [HMSO] UK Departement of Health. Nutritional aspects of cardiovascular disease (report on health and social subjects No. 46)., London (UK): HMSO. 1994

34. Felix, M.L.G.; Velazques, M. Food Chemistry. 2002, 96, 35-45. 